\title{
A józsefvárosi „TÁMASZ” Addiktológiai Gondozóban kezelt és 2001-2018-ban elhunyt betegek haláloki adatainak vizsgálata
}

\author{
Kalapos Miklós Péter dr. \\ Elméleti Biológiai Kutatócsoport, Budapest és Józsefvárosi „Szent Kozma” Egészségügyi Központ, \\ VIII. kerületi TÁMASZ Addiktológiai Gondozó, Budapest
}

\begin{abstract}
Bevezetés: A betegek haláloki adatainak feldolgozása az ellátás szempontjából fontos.
Célkitüzés: A józsefvárosi Addiktológiai Gondozóban kezelt és 2001 és 2018 között elhunyt betegek adatainak vizsgálata.

Módszer: A betegadatok a gondozó nyilvántartásából, az országos, illetve a budapesti adatok a Központi Statisztikai Hivatal hivatalos kiadványaiból származnak.

Eredmények: Az elhunyt betegek életkora nők esetében 52,85 $\pm 11,81$ év, míg férfiak esetében 51,99 $\pm 12,47$ év. Kétharmaduk, nemtől függetlenül, alkoholfüggő volt. Különösen sok erőszakos haláleset történt. Új jelenség a droghoz „kapcsolt” halálesetek és a gyilkosság áldozatává váltak magas száma. Az előbbiben férfi-, az utóbbiban női túlsúly volt. Az öngyilkosság miatt elhunytak aránya 14,6\%. Öngyilkossági kísérlet a betegek 22,4\%-ánál fordult elő. Az elhunyt betegek többsége szakmunkás volt.

Következtetések: Az adatok alátámasztják azt az ismert tényt, hogy az addiktológiai betegek korábban meghalnak. A korábbi vizsgálatokkal ellentétben vezető halálok az erőszakos halál. Az öngyilkosságot elkövetők aránya meghaladja az országos öngyilkossági arányt, ám a korábban közölt arányszámokkal megegyezik, ami ezen populáció magas veszélyeztetettségére utal. Az erőszakos halál vonatkozásában további vizsgálatokat igénylő nemi eltérések észlelhetők.
\end{abstract}

Orv Hetil. 2019, 160(47): 1864-1871.

Kulcsszavak: alkoholfüggőség, kémiaiszer-függőség, öngyilkosság, nemi különbség

Examination of the mortality data of patients, treated by the "TÁMASZ" Addictological Out-patient Clinic in Józsefváros (in Budapest, Hungary), who deceased in 2001-2018

Introduction: The analysis of the mortality data of patients is important.

Aim: Examination of data from patients treated in the Addictological Out-patient Clinic in Józsefváros and deceased between 2001 and 2018 .

Method: Patients' data originated from medical records. The national and Budapest data were from the publications of the Hungarian Central Statistical Office.

Results: The age of patients was $52.85 \pm 11.81$ years for women and $51.99 \pm 12.47$ years for men. Two-thirds, regardless of gender, were alcoholic. There were many violent deaths. A new phenomenon was the high number of drug- and murder-associated deaths. The former group was dominated by men. The latter group showed female dominance. The completed suicide rate was $14.6 \%$. Suicide attempts occurred in $22.4 \%$ of patients. The majority of patients were skilled workers.

Conclusion: Data support the view that addict patients die earlier. Leading deaths, unlike previous investigations, were violent deaths. The rate of suicide was higher than the national rate, but it was the same as previously reported, indicating a high risk of this population. Gender differences were observed with regard to violent death, requiring further elucidation.

Keywords: alcohol addiction, substance addiction, suicide, gender difference 
Kalapos MP. [Examination of the mortality data of patients, treated by the "TÁMASZ" Addictological Out-patient Clinic in Józsefváros (in Budapest, Hungary), who deceased in 2001-2018]. Orv Hetil. 2019; 160(47): 1864-1871.

(Beérkezett: 2019. június 18.; elfogadva: 2019. július 10.)

\section{Rövidítések}

BNO = Betegségek Nemzetközi Osztályozása; DSM = $($ Diagnostic and Statistical Manual of Mental Disorders) Mentális rendellenességek kórmeghatározó és statisztikai kézikönyve; GDP $=$ (gross domestic product) bruttó hazai termék; GNP = (gross national product) bruttó nemzeti össztermék; DALY = (disability adjusted life years) egészségkárosodással korrigált életévek; KSH = Központi Statisztikai Hivatal; SD = standard deviáció

$\mathrm{Az}$ addiktológiai betegségben szenvedők száma világszerte, ezen belül Magyarországon is, jelentős [1]. Miközben ez a betegpopuláció mind anyagi, mind pszichoszociális értelemben egyre nagyobb terhet ró a társadalomra, a jelenség maga egyszersmind éles, gyakran ideológiailag túlfütött vitákat is provokál.

Az anyagi terhek arányait szemléltetendő néhány adat. A millenniumot követő években az ausztrál költségvetés a GDP 2\%-át költötte ilyen természetű betegségek gyógyítására, míg a fejlődő országok a GNP 3-4\%-át fordították lakosaik pszichiátriai és addiktológiai problémáinak kezelésére [2,3]. Világviszonylatban a DALY 13\%-át a neuropszichiátriai betegségek teszik ki, amelyeken belül meghatározó súllyal esnek latba az addikciós betegségek (alkohol, kábítószer, dohányzás), és az említett három szenvedélybetegséggel összefüggő halálozási arány $12,4 \%[1,3,4]$. Becslések szerint az e szenvedélyekhez kapcsolódó életévveszteség világviszonylatban 8,9\% [1, 3]. A közép-európai régióban a teljes betegségteher 19,9-31,6\%-át teszik ki a neuropszichiátriai megbetegedések, ezen belül is kiemelten az addikciós betegségek [5]. Magyarországon a mentálhigiénés problémák közgazdasági terheinek kétharmada a nagy szenvedélybetegségek - alkohol- és drogfogyasztás, valamint dohányzás - kiváltotta neuropszichiátriai zavarok költségeiből adódik [1].

Emellett, vagy talán éppen emiatt, az ezen körbe tartozó betegek társadalmi elutasítottsága jelentős, még szakmai körökben is [6-9]. Mindezek különösen igazak a már megbetegedett szerhasználók, az addiktológiai betegek, elsősorban az alkohol- és drogbetegek esetében.

$\mathrm{Az}$ addiktív szerhasználat a társadalmi költségek mellett jelentős anyagi terhet ró a szerhasználóra is. Ám ugyanakkor társadalmi szinten a kémiaiszer-használók kezelése költséghatékony $[10,11]$. A kezelési formák egyike az addiktológiai gondozás, amely csak akkor lehet hatékony, ha térben és időben könnyen elérhető, és a kezelés maga szakszerü [12].

$\mathrm{Az}$ egészségügyi ellátók körében általánosan elfogadott, hogy a kórbonctani vizsgálat egyfajta visszajelzés a klinikus részére, és ezáltal egyszersmind egy minőségbiztosítási elem is. Könnyü belátni, hogy a járó betegként gondozott, elhunyt addiktológiai betegek halálozási adatainak, a halálozás okának és körülményeinek megismerése a beteggondozás minőségének javítása tekintetében hasznos.

Józsefvárosban az elmúlt negyven évben több felmérés készült az addiktológiai betegségek gyakorisága, azok lefolyása, a betegek pszichoszociális körülményei tekintetében és halálozási adatai vonatkozásában [9, 13-17]. Egy vizsgálat kivételével azonban mindegyik kutatás az alkoholproblémás betegre koncentrált.

A jelen dolgozatban a Budapest VIII. kerületi „TÁMASZ” Addiktológiai Gondozóban kezelt és 2001 és 2018 közötti időszakban elhunyt betegek halálozási és demográfiai adatainak összehasonlító vizsgálatát tűztük ki célul.

\section{Betegek és módszer}

A dolgozatban közölt ábrák és táblázatok a 2001. január 1. és 2018. december 31. között elhunyt, a gondozóban kezelt betegek adatait foglalják össze. A gondozóban nem addiktológiai problémával kezelt, de a jelzett időszakban elhunyt betegeket $(\mathrm{n}=8)$ ebben a vizsgálatban nem vettük figyelembe. A betegadatok a gondozó nyilvántartásából származnak. Az adatgyưjtés által felölelt periódus alatt a gondozóban 5 orvos dolgozott, és két gondozóvezető fóorvos váltotta egymást (2001-2008, illetve 2008-2019; az utóbbi főorvos 2002-től már a gondozóban dolgozott).

A BNO-10 szerinti diagnózisokat a kezelőorvosok adták. Érdemes megjegyezni, hogy a jelentős szerhasználati átfedések miatt, mivel e szerek jól tudják helyettesíteni egymást [18], gyakori az alkoholproblémás, különösen az F10.20 diagnózisú betegek esetében a nyugtató szedése és az attól való függés, illetve a többi szer használata mellett a nyugtatók szedése, esetenként abuzálása. Így az Fl3.20 diagnózist csak azok a betegek kapták, akiknél más függőség nem fordult elő (1. táblázat). Minden más esetben, a fent leírtak észben tartása mellett, a kezelőorvosok által adott kezelési fódiagnózisok (3-as csoport a kódoláskor) szolgáltak az adatfeldolgozás alapjául.

A dolgozatban közölt országos, illetve budapesti adatok a Központi Statisztikai Hivatal hivatalos kiadványaiból - STADAT 1.1. és 6.1.7. - származnak.

Az eredmények, ahol ez helyénvaló, átlag \pm SD értékként kerülnek bemutatásra. Tekintettel a csoportonkénti száznál alacsonyabb betegszámra, a dolgozatban a betegek vonatkozásában \%-os adatközlésre csak ott kerül sor, 
1. táblázat

Az elhunyt betegek által elsődlegesen használt abuzív szerek mintázata

\begin{tabular}{lcc}
\hline A fódiagnózis alapjául szolgáló abúzusszer & Férfi & Nő \\
\hline $\begin{array}{l}\text { Alkohol } \\
\text { abúzus F10.10 }\end{array}$ & 63 & 25 \\
függőség F10.20 & 60 & 2 \\
\hline $\begin{array}{l}\text { Opiátok } \\
\text { függőség F11.20 }\end{array}$ & 3 & 23 \\
\hline $\begin{array}{l}\text { Cannabis és származékai } \\
\text { függóség F12.20 }\end{array}$ & 2 & 0 \\
\hline $\begin{array}{l}\text { Nyugtatók és altatók } \\
\text { függőség F13.20 }\end{array}$ & 2 & 3 \\
\hline $\begin{array}{l}\text { Egyéb stimulánsok } \\
\text { abúzus F15.10 } \\
\text { függóség F15.20 }\end{array}$ & 2 & 0 \\
\hline $\begin{array}{l}\text { Illékony oldószer (spray/szipózás) } \\
\text { függóség F18.20 }\end{array}$ & 1 & 0 \\
\hline $\begin{array}{l}\text { Többféle drog } \\
\text { függóség F19.20 }\end{array}$ & 2 & 0 \\
\hline \begin{tabular}{l} 
Összes elhunyt beteg \\
\hline
\end{tabular} & 83 & 0 \\
\hline
\end{tabular}

aAz új pszichoaktív szerek (ÚPSZ, designer drogok) besorolása ide történt.

ahol az összes beteg körén belüli alcsoportok nagyságát adjuk meg. A szignifikanciaszámítás során a Student-féle t-próbát (kétmintás) alkalmaztuk, az elvárt szignifikanciaszint $\mathrm{p}<0,05$ volt. (A próba alkalmazhatóságának eldöntésére az F-próba került alkalmazásra.)

\section{Eredmények}

Korábban a gondozóban kezelt, elhunyt addiktológiai betegek átlagos életkora a halál bekövetkeztekor nók esetében $52,85 \pm 11,81$ év $(n=33$, terjedelem $31-84$ év, medián érték 53 év), férfiak esetében $51,99 \pm 12,47$ év ( $n=83$, terjedelem 19-84 év, medián érték 51 év) volt. A betegcsoport korosztály szerinti megoszlását nem szerinti bontásban az 1 ábra mutatja be.

A BNO-10 szerinti, a DSM-IV diagnosztikai kritériumain alapuló besorolás szerint az elhunyt betegek több mint kétharmada, nemtől függetlenül, alkoholfüggő volt (1. táblázat). Felmerült a kérdés, hogy a halálozáskori életkor tekintetében az alkoholfüggők eltérnek-e a többi szerfüggőtool (2. ábra). Nők esetében az alkoholfüggők, illetve az egyéb kémiaiszer-függőségekben szenvedők életkora a halál idején $54,64 \pm 9,83$ év $(\mathrm{n}=25)$, illetve $47,5 \pm 16,40$ év $(\mathrm{n}=8)$ volt. A hasonló adatok férfiak esetében $54,51 \pm 10,60$ év $(\mathrm{n}=63)$, illetve 44,30 \pm $14,33$ év ( $n=20)$ voltak. Bár az egyéb kémiaiszer-függöségben szenvedő elhunytak életkora 7-10 évvel alacsonyabb volt, mint az alkoholfüggőké, szignifikáns eltérés a két csoport között egyik nem esetében sem volt kimutatható.

A kémiai anyagok abuzív használata és a mentális zavarok gyakran együtt fordulnak elő [19].

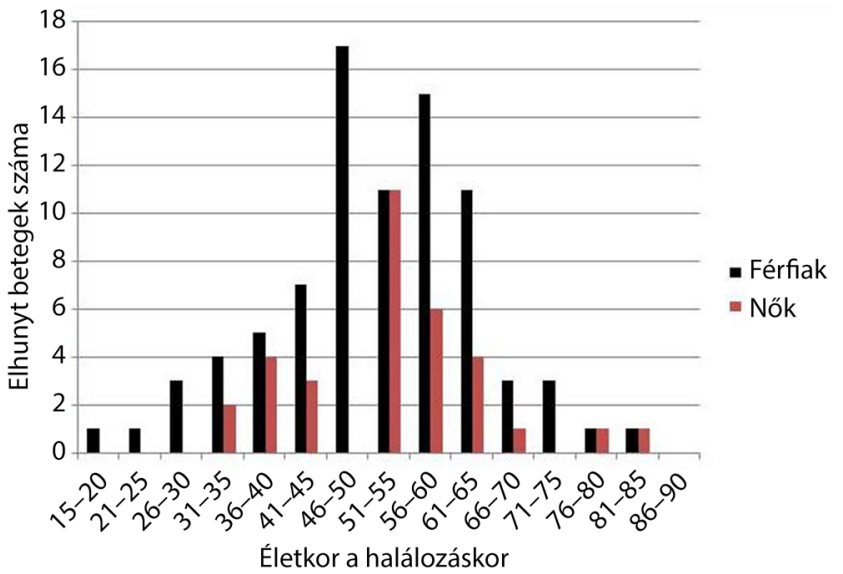

1. ábra

Az elhunyt betegek életkor szerinti hisztogramja nemenkénti bontásban

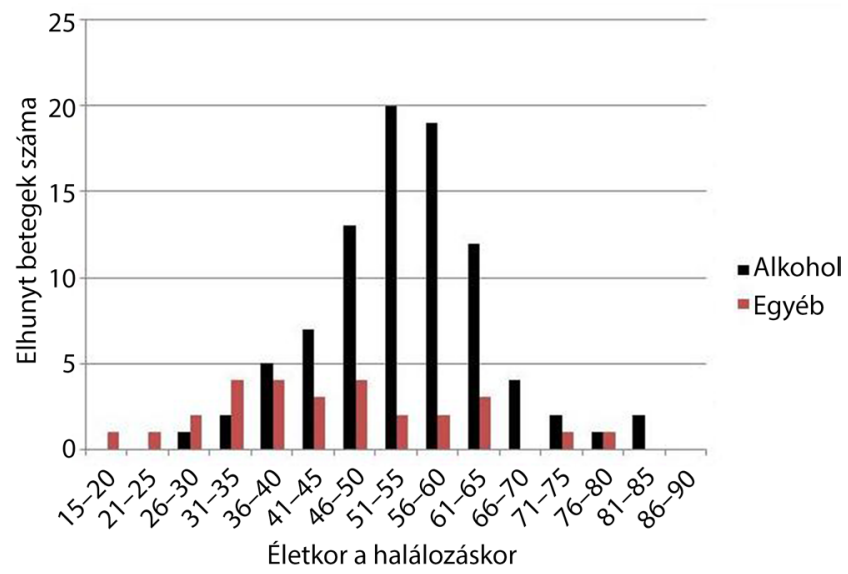

2. ábra

Az elhunyt betegek életkor szerinti hisztogramja a használt abúzusszer függvényében

A halálakor 65 éves, szakmunkás végzettségű beteget a gondozóban 13 éve ugyanaz az orvos kezelte. A gondozói kezelést megelőzően több alkalommal kezelték kórházi osztályon. Kiírási diagnózisai: szkizoaffektív betegség, alkoholdependencia. Utóbb leszázalékolták, már leszázalékoltan került a gondozóba, miután a kórház, amely korábban járó betegként is kezelte, kezelését nem vállalta tovább. Anamnézisében két alkalommal megkísérelt suicidium szerepelt. Pater etilizált, egyebekben a családi anamnézis negatív. Nejével élt eleinte együtt, majd külön költözött. Egy fiúgyermekük volt.

Kezelése során riszperidon $3 \times 1 \mathrm{mg}$ és klonazepám $3 \times 1 \mathrm{mg}$ alkotta a báziskezelést, ami esetenként antidepresszánssal (tianeptin) egészült ki. Rendszeresen járt a gondozóba, évekig havonta, majd az utolsó négy évben kéthavonta. Olykor-olykor sörözött, de lerészegedés nem volt. Gyanakvása mindvégig megmaradt, de a kezelőorvossal kooperált. Az alacsonyabb fekvésû́ hangulat és kóros jelentőségtulajdonítás, enyhe grimaszolás mindvégig jelen voltak. 
A halálozás oka a VIII. kerületi gondozóban kezelt betegek esetén

\begin{tabular}{|c|c|c|}
\hline A halál oka & Férfi & Nő \\
\hline Erôszakos cselekmény & 11 & 9 \\
\hline öngyilkosság & 6 & 5 \\
\hline drogtúladagolás ${ }^{a}$ & 5 & 1 \\
\hline gyilkosság & 0 & 3 \\
\hline Daganatos megbetegedés & 5 & 3 \\
\hline tüdő & 2 & 1 \\
\hline prosztata & 1 & 0 \\
\hline nőgyógyászati & 0 & 1 \\
\hline szájüregi & 1 & 0 \\
\hline gyomor & 1 & 0 \\
\hline nem specifikált & 0 & 1 \\
\hline Cirrhosis $^{\mathrm{b}}$ & 4 & 1 \\
\hline májelégtelenség & 2 & 1 \\
\hline nyelőcsővérzés & 2 & 0 \\
\hline Egyéb tápcsatorna-betegség & 5 & 0 \\
\hline gyomorvérzés & 1 & 0 \\
\hline pancreatitis & 4 & 0 \\
\hline Cardiovascularis & 5 & 6 \\
\hline stroke & 1 & 0 \\
\hline szívhalálc $^{c}$ & 4 & 6 \\
\hline Egyéb & 2 & 1 \\
\hline pneumonia & 0 & 1 \\
\hline tüdőembólia & 1 & 0 \\
\hline szepszis & 1 & 0 \\
\hline Nincs adat & 51 & 13 \\
\hline Összes elhunyt beteg ${ }^{d}$ & 83 & 33 \\
\hline
\end{tabular}

"Véletlen szertúladagolás (ismeretlen szer és/vagy ismeretlen helyen), illetve szándékolt (úgynevezett aranylövés).

${ }^{b}$ E helyen csak akkor szerepel a cirrhosis, ha a beteg halálában közvetlenül szerepet játszó szövődményről volt szó. Az elhunytak döntő részének volt májbetegsége.

'Myocardialis infarctus és cardialis elégtelenség

dA férfi betegek közül 21, a nőbetegek közül 3 volt hajléktalan.

Diagnózisai: F2590/1 Nem meghatározott szkizoaffektív zavar, F1020/3 Alkohol okozta dependencia (szindróma), F4110/4 Generalizált szorongás, G2560/4 Gyógyszer indukálta és egyéb szervi eredetű ticek, K7090/4 Alkoholos májbetegség, k.m.n., El490/4 Cukorbetegség k.m.n., N4000/5 Prosztatatúltengés.

Az exitust megelőzően 8 nappal járt a gondozóban, panasza nem volt. A kezelőorvossal beszélt, receptet kapott, és két hónapra visszarendelték kontrollra.

Az exitusról. Otthonában találták fel (a feleség telefonált a gondozóba). Az idegenkezűséget kizárták. Sectio (a dokumentációt a családtag bemutatta) a halál okaként szívelégtelenséget állapított meg, emellett általános érelmeszesedést írt le. A toxikológiai vizsgálat eredményei: véralkohol 0,228 (g/l) \%, $810,9 \mathrm{mg} / \mathrm{ml}$ koffein, $58,6 \mathrm{mg} / \mathrm{ml} 7$-aminoklonazepám, $23 \mathrm{mg} / \mathrm{ml}$ riszperidon.

Az esetleírásból látható, hogy az úgynevezett kettős diagnózis - pszichiátriai betegség diagnózisa az addiktológiai diagnózis mellett - betegeink körében is előfordult.
3. táblázat Az öngyilkosság súlya az összes haláleseten belül a teljes populá ció, illetve a vizsgált betegkör esetén

\begin{tabular}{lcc}
\hline $\begin{array}{l}\text { Vizsgált } \\
\text { időszak }\end{array}$ & $\begin{array}{c}\text { A periódusra } \\
\text { számított országos, } \\
\text { átlagos évi öngyilkos- } \\
\text { sági arány (\%) }\end{array}$ & $\begin{array}{c}\text { A vizsgált időszakban öngyilkos- } \\
\text { ság miatt elhunyt gondozott } \\
\text { addiktológiai betegek dolgoza- } \\
\text { tokban közölt aránya (\%) }\end{array}$ \\
\hline $1961-1970^{\mathrm{a}}$ & $2,81 \pm 0,21 \%^{\mathrm{b}}$ & $23,9 \%$ \\
$1971-1975^{\mathrm{c}}$ & $3,17 \pm 0,14 \%^{\mathrm{d}}$ & $8,1 \%$ \\
$1976-1980^{\mathrm{c}}$ & $3,32 \pm 0,09 \%^{\mathrm{d}}$ & $9,24 \%$ \\
$2001-2018$ & $1,81 \pm 0,28 \%^{\mathrm{f}}$ & $9,48 \%($ drogosok nélkül) \\
& & $14,6 \%\left(\right.$ drogosokkal) ${ }^{\mathrm{g}}$ \\
\hline
\end{tabular}

a[13] alapján

'Enyhe emelkedés az adott periódusban.

c[14] alapján

dJelentősebb emelkedés az adott periódusban.

‘[15] alapján

'Markáns csökkenés az adott periódusban.

${ }^{g}$ Aranylövés, túladagolás is itt szerepel.

4. táblázat $\mid$ Az elhunyt betegek iskolai végzettség szerinti megoszlása

\begin{tabular}{lcc}
\hline Iskolai végzettség & Férfi & Nő \\
\hline$<8$ általános iskola & 2 & $1^{\mathrm{a}}$ \\
8 általános iskola & 10 & 8 \\
Szakmunkásképző & 30 & 7 \\
Érettségi/technikum & 15 & 5 \\
Fóiskola & 4 & 2 \\
Egyetem & 8 & 3 \\
Nincs adat & 14 & 7 \\
\hline Összesen & 83 & 33 \\
\hline
\end{tabular}

${ }^{\mathrm{a}} \mathrm{Ez}$ az idősebb beteg írástudatlan volt.

Az elhalálozások okát illetően meglehetősen hiányosak az adatok, mert az ok az esetek jelentős részében nem volt felderíthető (2. táblázat). A táblázatban bemutatott adatokból is kiviláglik azonban az erőszakos halálesetek különösen magas aránya. A 2001-2018-as időszakban öngyilkosság miatt elhunyt, gondozott addiktológiai betegek aránya a teljes mintát tekintve 14,6\%, míg csak az alkoholfüggó betegekre szorítkozva ez az érték 9,48\% (3. táblázat). E tekintetben érdemes kiemelni, hogy az anamnesztikus adatok szerint öngyilkossági kísérlet 17 férfi beteg, illetve 9 nőbeteg esetében fordult elő, ami a teljes mintára vetítve a betegek $22,4 \%$-át jelenti.

Az iskolai végzettség tekintetében az elhunyt betegek többsége maximum szakmunkásvégzettséggel rendelkezett (4. táblázat).

\section{Megbeszélés}

Budapest VIII. kerülete, Józsefváros, lakosságának addiktológiai - döntően alkoholfogyasztási - szempontból történő vizsgálata mintegy ötvenéves múltra tekint viszsza. A betegséggyakoriság és -lefolyás, a betegek pszi- 
choszociális körülményei és halálozási adatai álltak a vizsgálatok középpontjában [12-17]. Bár a kerület lakosságának összetétele nem reprezentálja a budapesti lakosság összetételét, és Józsefvárost a közbeszédben, valamint a szakmai diskurzusokban is az addiktológiai szempontból fertőzöttebb kerületek közé sorolják, ez az egyetlen budapesti kerület, ahol a területi addiktológiai ellátók múködéséről több évtizedre visszatekintően tudományosan dokumentált adatok állnak rendelkezésre. A közlemények e sora alkalmat nyújt összehasonlító vizsgálatokra is. A jelen dolgozatban a szerző a kerületi addiktológiai gondozóban kezelt és 2001-2018-as időszakban elhunyt betegek halálozási és demográfiai adatainak öszszehasonlító vizsgálatát tûzte ki célul.

Az elhunyt, korábban a gondozóban kezelt addiktológiai betegek átlagos életkora a halál bekövetkeztekor nók esetében 52,85 $\pm 11,81$ év, míg férfiak esetében 51,99 \pm 12,47 év volt. A jelzett időszakban Budapesten a várható élettartam nők esetében 76,52 évról 80,06 évre, míg férfiak esetében 69,28 évről 74,27 évre nőtt. (Az országos adatok 76,46-ról 78,99 évre, illetve 68,15-ról 72,40 évre történő növekedést mutatnak.) A hetvenéves kort mindösszesen hét beteg (6,03\%) élte meg (1. ábra). A teljes népességre vonatkozó KSH-adatok szerint 2018ban a magyar lakosság 12,78\%-a volt hetvenéves vagy annál idősebb. Mindezen adatok együttesen alátámasztják azt a szakirodalomból is ismert tényt, hogy az addiktológiai betegek korábban meghalnak, mint nem addiktológiai kortársaik [20, 21].

Bár a dolgozatban közölt adatok egybeesnek Kollerits és mtsa korábbi eredményeivel, mindazonáltal az lényegi eltérést jelent a korábbi közlésektől, hogy a jelen dolgozatban drog- és gyógyszerfüggő betegek adatai is szerepelnek (1. táblázat), míg a korábbi munkák csupán alkoholproblémás betegek adatait tartalmazták [13-15]. Az egyes addiktológiai kórképek - drog- és alkoholfüggés, dohányzás - gyakran társulnak egymással, és ehhez gyakorta társul a nyugtatófüggőség is. Ennek egyik oka, hogy e szerek jól tudják egymást helyettesíteni [18].

$\mathrm{Az}$ alkoholfüggőkre vonatkozó adatok mind a nők, mind a férfiak esetében magasabb halálozási életkort mutattak, szemben a nem alkohol-, hanem más kémiaiszerfüggők (döntően kábítószerfüggők) hasonló adataival. Jóllehet az eltérés nem bizonyult szignifikánsnak, feltehető, hogy ezen utóbbi csoport körében a halál fiatalabb életkorban következik be, mint az alkoholfüggő betegek esetében (2. ábra). Erre utalnak a nemzetközi vizsgálatok eredményei is [22].

Korábbi adatok szerint a józsefvárosi alkoholgondozóban kezelt betegek halálozásáért közel egyharmad arányban a cardiovascularis betegségek, közel ötödükhatoduk esetében a májcirrhosis, illetve hatoduknál a daganatos betegségek voltak felelősek [13-15]. Ugyanakkor közel tizedük halála öngyilkosság miatt következett be [13-15].

A jelen dolgozat adatai a fentieket csupán részben erősítik meg. Jóllehet mind a cardiovascularis betegségek, mind pedig a májcirrhosis, illetve a daganatos betegségek szerepelnek halálokként, a vezető halálok mégis az erőszakos okból bekövetkezett halál (2. táblázat). A vizsgálatokban észlelt adatok közötti különbségek okai az alábbiakban foglalhatók össze.

Korábban, miként munkáikban a szerzők is utaltak rá [13-15], létezett a kötelező kezelés intézménye. Ez alapvetően az 1978. évi IV. törvény 76. \$-án alapult, amelyet a hozzá kapcsolódó rendeletekkel együtt az 1990. évi XIV. törvény „Az alkoholisták bíróság által elrendelt intézeti gyógykezelésének megszüntetéséről”

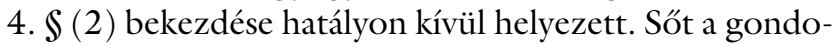
zó maga a Patológiai Osztállyal rendelkező Fővárosi Balassa Kórház járóbeteg-ellátó intézménye volt, és e két tényező egyrészt magasabb betegszámot (így magasabb volt az elhunytak száma is), másrészt egyfajta szorosabb kontrollt és egyszersmind információáramlást is jelentett. E kapcsolat hiánya visszatükröződhet abban is, hogy a 2001-2018-as időszakban elhunyt betegek esetében különösen a férfiak csoportjában - a halál oka tekintetében az esetek jelentős hányadában nem állt rendelkezésre információ (2. táblázat). Ha a kérdést tovább szálazzuk, akkor figyelembe kell venni, hogy a hajléktalanok száma a férfi és a nőbetegek között jelentősen eltért, ami a visszajelzések tekintetében mindenképp meghatározó, különösen, ha figyelembe vesszük, hogy a visszajelzések döntő hányada a családtól és nem hivatalos csatornákon érkezett (2. táblázat, esetleírás).

A halálesetek között az öngyilkosságot elkövetők aránya közel 10\%, ami jóval meghaladja a periódusra számított évi átlagos, országos öngyilkossági arányt, és arányában megegyezik a korábbi dolgozatokban közölt arányszámokkal, illetve ami, tekintettel a nem ismert halálokok magas számára, bizonyosan a valós szám alulbecslése (2. és 3. táblázat). Mindezek a számok különösen annak fényében tragikusak, hogy mindeközben a befejezett öngyilkosságok száma Magyarországon a hatékony terápiának köszönhetően csökkent [23].

Újdonságot jelent a droghoz „kapcsolt” halálesetek és a gyilkosság áldozatává váltak magas száma (2. táblázat). Ám míg az előbbiben férfitúlsúly észlelhető, a gyilkosságok áldozatai mind nők (2. táblázat). Mindezek a nemi eltérésekre hívják fel a figyelmet, és további vizsgálatokat igényelnek.

Az öngyilkossági esetek magas száma mellett jelentős volt az öngyilkosságot megkísérlők száma is, a teljes minta esetében 22,4\%. Az öngyilkosság (kísérlet, befejezett) és a kémiaiszer-használat, -függőség kapcsolata szoros; italozás a családban vagy a beteg anamnézisében rizikófaktor [24]. Epidemiológiai vizsgálatok szerint a befejezett öngyilkosságot elkövetók - az elkövetés módjától függően - 10-60\%-a alkoholfüggő vagy abuzőr, továbbá az ilyen egyének nem elhanyagolható hányada, hozzávetőleg 40\%-a, alkoholfogyasztást követően vagy alkoholosan intoxikált állapotban követte el tettét [1, 25]. Emellett úgy tûnik, hogy a suicidiumot elkövetők 40-70\%-ánál pozitív a toxikológiai vizsgálat eredménye; a legjelentő- 
sebb az alkohol, de más abuzív szerek (cannabis, benzodiazepin, opiátok, amfetamin) szerepe sem elhanyagolható [26]. Ha azonban csak a szertúladagolás miatt meghaltak adatait vesszük tekintetbe, akkor a vezetô szerek az opiátok és a benzodiazepinek [26]. Másik oldalról, a jelen dolgozathoz jobban illeszkedő módon megközelítve a kérdést, élete során az alkoholfüggő́k negyede-fele kísérel meg öngyilkosságot, és 2-7\%-a emiatt exitál [27]. A józsefvárosi adatok némileg magasabb rátát mutatnak a befejezett öngyilkosság vonatkozásában, mint a nemzetközi adatok. Ez a különbség adódhat a kisebb betegszámból, illetve abból, hogy magyar betegekről van szó, és minden csökkenés dacára, a suicidiumráta Magyarországon sajnos még mindig magas.

Az esetleírás megerősíti ugyan azt a szakirodalomból jól ismert jelenséget, hogy a kémiai anyagok abuzív használata és a pszichiátriai betegségek gyakran együtt fordulnak elő, a dolgozatban azonban pszichiátriai diagnózis szerinti alcsoportképzés nem történt. Bár összesen 116 beteg adatait dolgoztuk fel, ami elvileg egy ilyen alcsoport szerinti beosztást lehetővé tehetett volna, a 88 alkoholproblémás beteg mellett a kisebbik csoportba - F11.20-F19.20 (1. táblázat) - csupán 28 beteg került volna, ami csoportként néhány beteget jelentett volna. Továbbá a betegek jelentős hányadánál a gondozóba kerülés előtti időszakról nem állt rendelkezésre, illetve nem volt megszerezhető megbízható dokumentáció. Így a jelentôs tünettani átfedés - például vonatkoztatás mind pszichiátriai betegség, mind kémiaiszer-használat miatt kialakult állapot esetén előfordulhat - az anamnesztikus adatok bizonytalansága miatt a korrekt alcsoportokba sorolás gátját képezte.

$\mathrm{Az}$ alkohol- és drogfüggő betegek többségének komorbid testi és/vagy pszichiátriai betegsége is van, amelyre egyrészt csak kis részük kap adekvát kezelést - különösen, ha hajléktalan a beteg; ennek rendszerszintú és egyéni okai egyaránt vannak -, másrészt a komorbid állapotok kórjóslata rosszabb, kezelésük nehezebb [1]. Ez részben magyarázata lehet az addikt betegek körében észlelt magas öngyilkossági (kísérlet, befejezett) rátának (3. táblázat).

Iskolai végzettség tekintetében a korábbi közlemények adatai és a 4. táblázat adatai jó egyezést mutatnak [13-15]. Bár a skála az alig iskolázottságtól (beleértve az írástudatlanságot is) az egyetemi végzettségig terjed, a legnagyobb csoportot a szakmunkás végzettségúek csoportja adja (4. táblázat). Ebben az elmúlt évtizedekben nem történt változás, aminek okai nem kellően feltártak.

Nemzetközi vizsgálatok szerint az orvosok nehezen állítják fel az alkohol-drog betegség diagnózisát, és esetenként különböző fedődiagnózisokat adnak, nem is ritkán a család vagy a beteg nyomására, ugyanakkor hajlamosabbak szerfüggőséget diagnosztizálni, ha a beteg alacsonyabb társadalmi rétegbe tartozik $[1,28-30]$. A gyógyszerfüggőség kialakulásában pedig jelentős a iatrogénia [1].
Bár a tekintetben vita van, hogy a társadalmi státusz milyen mértékben határozza meg a diagnózist, addiktológiai/pszichiátriai betegségek esetében az előítéletre épülő stigmatizáció mindenképp torzító tényezőként hathat [31-33]. A súlyos mentális egészségi problémák és a gyakran kórházi ápolásra szoruló betegségek prevalenciája magasabb a szegények és a hajléktalanok körében [34-37]. A hajléktalanok gyakrabban szenvednek krónikus pszichiátriai zavaroktól és/vagy kémiaiszerfüggőségtől, mint a normálnépesség tagjai, ami felveti a tyúk-tojás dilemmát $[34,38]$. Mintánkban is jelentős a hajléktalanok reprezentációja, különösen a férfiak esetében. Korábbi tanulmányok hajléktalanságról még nem tettek említést [13-15]. Összességében joggal feltételezhetjük, hogy a társadalmi tóke befolyással bír a mentálisan betegek, így az addiktológiai betegek sorsára is.

Tengerentúli vizsgálatok szerint a háziorvosok legtöbbje a rutinvizsgálatok során betege alkohol- vagy drogfüggőségére rá sem kérdez, mert elvesztegetett időnek tartja azt az időt, amit a kémiaiszer-fogyasztás felderítésére szánna [28, 29]. Egy korábbi, Józsefvárosban praktizáló háziorvosok és szakorvosok körében végzett, addiktológiai beteget ellátó attitúdjüket és tudásukat is vizsgáló önbevallásos kérdőíves adatgyưjités eredményeiből kiderült, hogy az orvosok túlnyomó többsége, ha felmerül, nem csupán rákérdez betege kémiaiszer-fogyasztására (a háziorvosok mindegyikére, míg a szakorvosok többségére igaz volt ez a megállapítás), hanem szakorvoshoz is irányítja a beteget [9]. Ezt a válaszok alapján kirajzolódó, az egyesült államokbeli helyzettól pozitív irányban eltérő viselkedést a mindennapi addiktológiai gyakorlat nem igazolja vissza [9]. A diszkrepancia a válaszok és a gyakorlat között több kérdést is felvet, az affektív/kognitív torzítástól az egyes orvosi szakágak múvelői közötti kommunikáció zavaráig.

\section{Korlátok, következtetések és javaslat a jövőbeli irányokra}

Egy betegség/káros szokás népesség körében való elterjedtségének ismerete nélkül nem lehetséges megfelelő programokat kidolgozni a betegség/káros szokás egészségügyi hatásainak kivédésére, illetve a már kialakult károsodás kezelésére. Hasonlóan fontos egy adott beavatkozás eredményének/eredménytelenségének visszajelzése. Az elhunyt betegek haláloki adatainak elemzése a minta szintjén nyújtana lehetőséget a helyi szintú ellátás korrekciójára. Ami a korlátja, az egyben az erőssége is a tanulmánynak, egy adott kerületre vonatkozó adatokat mutat be. Ám így lehetőség nyílik több mint fél évszázad tendenciáinak áttekintésére. A dolgozatban bemutattuk, a korábbiakkal összehasonlítva lötyögősebben múködik a rendszer, ami a megalapozott következtetések levonásának egyik korlátja. Pedig a mortalitási adatgyújtés a gondozási munka minőségének javítása tekintetében is fontos lenne! Ezért célszerü lenne a hazai lehetőségek mérlegelésével egy addiktológiai morbiditási adatgyúj- 
tési programot megvalósítani és egy addiktológiai betegregisztert létrehozni.

A fent leírtak dacára megerősítést nyert, hogy a kémiaiszer-függő betegek várható élettartama lényegesen alacsonyabb mind az országos, mind a budapesti átlagnál, és az elhunyt addiktológiai betegek többsége 30-70 éves kora között halt meg. Bár iskolai végzettség tekintetében a skála az alig iskolázottságtól az egyetemi végzettségig terjed, többségben a szakmunkás végzettségüek csoportja van. Vagyis, legalábbis a Józsefvárosban, az elmúlt 30-40 évben a halálozási mutatók javítása tekintetében előremozdulás nem történt. Ennek oka számos lehet, ám ha a szikár statisztikai adatokat nézzük, akkor azokból kiviláglik, hogy egyrészt az addikciós problémáktól szenvedők száma Magyarországon több százezres populációt jelent, másrészt az is látható, hogy a gondozókban nyilvántartott alkoholproblémás betegek száma az elmúlt másfél évtizedben jelentősen csökkent, és e csökkenés különösen markáns a férfiak esetében [1, 12]. Emellett az egy naptári évben regisztrált drogproblémások 40 50\%-a eltûnik a rendszerből [12].

De ha a gondozást igénylő addiktológiai betegek eltünnek az addiktológiai ellátórendszerből, akkor felmerül a kérdés: végül is hol, ha egyáltalán (!), kerülnek be az egészségügyi ellátórendszerbe, és milyen eséllyel gyógyulnak?

$\mathrm{Az}$ addiktológiai betegek sikeres kezelése és ellátása multidiszciplináris gyógyító stáb együttmúködését, a területi ellátók és alacsonyküszöbü szolgáltatók kooperációját igényelné! Jelenleg a rendszer a fragmentált ellátás irányába mozog, a betegutak esetlegessé váltak, ami nem csupán a betegbiztonságot és a hozzáférést veszélyezteti, de rontja az adherenciát is. Így egy circulus vitiosus alakul ki, ami vagy az addiktológiai betegek ellátatlanságához, vagy magasabb szintű egységek túlterheléséhez vezet. Ezért elkerülhetetlen a kerületi ellátók összevonása, ami a humánerőforrás egyfajta centralizációjával a betegbiztonságot is növeli.

Anyagi támogatás: A szerző anyagi támogatásban nem részesült.

A szerző a cikk végleges változatát elolvasta és jóváhagyta.

Érdekeltségek: A szerzőnek nincsenek érdekeltségei.

\section{Köszönetnyilvánítás}

A szerző köszönetet mond Mazurné Borbély Margit és Nemes Anna adminisztrátoroknak az adatgyűjtésben nyújtott segítségükért.

\section{Irodalom}

[1] Kalapos MP. Introduction to addictology. [Bevezetés az addiktológiába.] Medicina Könyvkiadó, Budapest, 2016. [Hungarian]

[2] Shanahan M, Havard A, Teesson M, et al. Patterns and costs of treatment for heroin dependence over 12 months: findings from the Australian Treatment Outcome Study. Aust N Z J Public Health 2006; 30: 305-311.

[3] WHO. Investing in mental health. Department of Mental Health and Substance Dependence, Noncommunicable Diseases and Mental Health, World Health Organization, Geneva, 2003. Available from: http://www.who.int/iris/handle/10665/ 42823 [accessed: October 10, 2019].

[4] GBD 2016 Alcohol and Drug Use Collaborators. The global burden of disease attributable to alcohol and drug use in 195 countries and territories, 1990-2016: a systematic analysis for the Global Burden of Disease Study 2016. Lancet Psychiatry 2018; 5: 987-1012. Correction: Lancet Psychiatry 2019; 6(1): e2.

[5] WHO. Mental Health Atlas - 2011, country profiles. World Health Organization, Geneva, 2011. Available from: http:// www.who.int/mental_health/evidence/atlasprofile [accessed: October 10, 2019].

[6] Miller NS, Sheppard LM, Colenda CC, et al. Why physicians are unprepared to treat patients who have alcohol- and drug-related disorders. Acad Med. 2001; 76: 410-418.

[7] Barth Á, Demetrovics Zs, Bodnár G. Knowledge of and attitudes toward drug addicts and their treatment among psychiatrists. [Drogfüggő betegek kezelésével kapcsolatos ismeretek és attitüdök vizsgálata pszichiáter szakorvosok körében.] Mentálhig Pszichoszomat. 2007; 8: 179-192. [Hungarian]

[8] Elekes Zs, Paksy B. Alcohol and other drug use among adults aged 18-54. [A 18-54 éves felnőttek alkohol- és egyéb drogfogyasztása.] Kézirat, 2003. (Hivatkozás a Jelentés a magyarországi droghelyzetról címú, 2004-es kiadványban) [Hungarian]

[9] Kalapos MP. Investigation of the frequency of alcohol related problems in Józsefváros, Budapest. Data and conclusions of three surveys undertaken among doctors and out-patients. $[\mathrm{Az}$ alkoholprobléma gyakoriságának vizsgálata Józsefvárosban. Betegek és orvosok körében végzett felmérések eredményei.] Orv Hetil. 2012; 153: 1263-1280. [Hungarian]

[10] Cartwright WS. Cost-benefit analysis of drug treatment services: review of the literature. J Ment Health Policy Econ. 2000; 3: 11-26.

[11] Popova S, Mohapatra S, Patra J, et al. A literature review of costbenefit analyses for the treatment of alcohol dependence. Int J Environ Res Public Health 2011; 8: 3351-3364.

[12] Kalapos MP. To tend or not to tend? Why tending of addict clients is avoided whereas the social benefit of tending is higher than the cost of treatment? [Gondozni vagy nem gondozni? Ha a gondozás társadalmi haszna nagyobb, mint költsége, akkor miért nem valósul meg?] IME 2018; 17(2): 36-44. [Hungarian]

[13] Kollerits I, Bálint I. Examination of death data of alcoholic patients. [Alkoholista betegek haláloki adatainak vizsgálata.] Alkohológia 1971; 2: 143-147. [Hungarian]

[14] Kollerits I. Comparative study of mortality data of alcoholic patients. [Alkoholista betegek haláloki adatainak összehasonlító vizsgálata.] Alkohológia 1977; 8: 82-86. [Hungarian]

[15] Kollerits I. A 20-year comparative study of mortality data of alcoholics treated in the out-patient clinic of the district of VIII. [A VIII. kerületi alkoholgondozóban kezelt betegek haláloki adatainak 20 éves összehasonlító vizsgálata.] Fővárosi Balassa Kórház Orvosi Közleményei 1986; 20: 143-146. [Hungarian]

[16] Kopp M, Ratkóczi É. Comparative psychiatric epidemiological study of two medical districts of Budapest, Józsefváros. [Budapest Józsefváros két orvosi körzetének összehasonlító pszichiátriai epidemiológiai vizsgálata.] Társadalmi beilleszkedési zavarok bulletin, 14. szám. MSZMP KB Társadalomtudományi Intézet, Budapest, 1989. [Hungarian]

[17] Kalapos MP. 3,4-methylene-dioxy-pyrovalerone (MDPV) epidemic? [3,4-metilén-dioxi-pirovaleron (MDPV) epidémia?] Orv Hetil. 2011; 152: 2010-2019. [Hungarian]

[18] Gerevich J. Aspects of out-patient treatment of drug users. In: Németh A, Gerevich J. (eds.) Addictions. [A drogfogyasztók 
ambuláns kezelésének szempontjai. In: Németh A, Gerevich J. (szerk.) Addikciók.] Medicina Könyvkiadó, Budapest, 2000; pp. 52-72. [Hungarian]

[19] McGovern MP, Lambert-Harris C, Gotham HJ, et al. Dual diagnosis capability in mental health and addiction treatment services: an assessment of programs across multiple state systems. Adm Policy Ment Health 2014; 41: 205-214.

[20] Peterson B, Kristenson H, Sternby NH, et al. Alcohol consumption and premature death in middle-age men. Br Med J. 1980; 280: 1403-1406.

[21] Just JM, Bleckwenn M, Schnakenberg R, et al. Drug-related celebrity deaths: a cross-sectional study. Subst Abuse Treat Prev Policy 2016; 11: 40.

[22] Hjemsaeter AJ, Bramness JG, Drake R, et al. Mortality, cause of death and risk factors in patients with alcohol use disorder alone or poly-substance use disorders: a 19-year prospective cohort study. BMC Psychiatry 2019; 19: 101

[23] Rihmer Z, Gonda X, Kapitány B, et al. Suicide in Hungary-epidemiological and clinical perspectives. Ann Gen Psychiatry 2013; 12: 21 .

[24] Rihmer, Z. Suicide. In: Füredi J, Németh A, Tariska P. (eds.) Hungarian handbook of psychiatry. 3rd edition. [Öngyilkosság. In: Füredi J, Németh A, Tariska P. (szerk.) A pszichiátria magyar kézikönyve. 3. kiadás.] Medicina Könyvkiadó, Budapest, 2003; pp. 721-728. [Hungarian]

[25] Cherpitel CJ, Borges GL, Wilcow HC. Acute alcohol use and suicidal behavior: a review of the literature. Alcohol Clin Exp Res. 2004; 28(5 Suppl): 18S-28S.

[26] Shields LB, Hunsaker DM, Hunsaker JC 3rd, et al. Toxicologic findings in suicide: a 10-year retrospective review of Kentucky medical examiner cases. Am J Forensic Med Pathol. 2006; 27: 106-112

[27] Pirkola SP, Suominen K, Isometsä ET. Suicide in alcoholdependent individuals. Epidemiology and management. CNS Drugs 2004; 18: 423-436.

[28] Moore RD, Bone LR, Geller G, et al. Prevalence, detection, and treatment of alcoholism in hospitalized patients. JAMA 1989; 261: 403-407.
[29] McLellan AT, Lewis DC, O'Brien CP, et al. Drug dependence, a chronic medical illness. Implications for treatment, insurance, and outcomes evaluation. JAMA 2000; 284: 1689-1695.

[30] Kalapos MP. Introduction to alcohology. [Bevezetés az alkohológiába.] Medicina Könyvkiadó, Budapest, 2007. [Hungarian]

[31] Corrigan PW, Watson AC. Understanding the impact of stigma on people with mental illness. World Psychiatry 2002; 1: 16-20.

[32] Thornicroft G, Rose D, Kassam A, et al. Stigma: ignorance, prejudice or discrimination? Br J Psychiatry 2007; 190: 192-193.

[33] Kalapos MP. Penrose's law: methodological challenges and call for data. Int J Law Psychiatry 2016; 49: 1-9.

[34] Molnár G. The homeless health care services, with special respect to their psychological state. In: Glatz F. (ed.) Living situation, quality of life, dead-ends and ways out. [A hajléktalanok egészségügyi ellátása, különös tekintettel pszichés állapotukra. In: Glatz F. (szerk.) Élethelyzet-életminőség, zsákutcák és kiutak.] Magyar Tudományos Akadémia, Budapest, 2002; pp. 137-161. [Hungarian]

[35] Murali V, Oyebode F. Poverty, social inequality and mental health. Adv Psychiatr Treat. 2004; 10: 216-224.

[36] Molarius A, Berglund K, Eriksson C, et al. Mental health symp toms in relation to socio-economic conditions and lifestyle factors - a population based study in Sweden. BMC Public Health 2009; 9: 302 .

[37] Hamano T, Fujisawa Y, Ishida Y, et. al. Social capital and mental health in Japan: a multilevel analysis. PLoS ONE 2010; 5: el3214.

[38] Fazel S, Khosla V, Doll H, et al. The prevalence of mental disorders among homeless in western countries: systematic review and meta-regression analysis. PLoS Med. 2008; 5: e225.

\title{
MEGHÍVó
}

\author{
A Szent János Kórház és Észak-budai Egyesített Kórházak Tudományos Bizottsága \\ tisztelettel meghívja az érdeklődőket a következő tudományos ülésére, amelyet \\ az I. Belgyógyászati és Gasztroenterológiai Osztály és a Magyar Gasztroenterológiai Társaság rendez. \\ Időpont: 2019. december 5. (csütörtök) 15 óra \\ Helyszín: Szent János Kórház Auditóriuma - 1125 Budapest, Diós árok 1-3. \\ Téma: „A Helicobacter pylori: aktualitások, érdekességek” \\ Üléselnök: Dr. Székely György és dr. Katona Márta
}

\section{Program:}

Dr. Pogány Péter: Helicobacter pylori asszociált gastritisek a patológus szemszögéből

15 perc

Dr. Tóth Gábor Tamás: Furcsa összefüggések: A Helicobacter pylori fertőzés és a gyulladásos bélbetegségek 10 perc

Dr. Sike Róbert: A Helicobacter pylori carcinogenitásának aktuális kérdései 10 perc

Dr. Katona Márta: A Helicobacter pylori eradikáció új szemlélete 10 perc

Dr. Székely György: A Helicobacter pylori, a microbiom és dysbiosis - tények és feltételezések 10 perc

$$
\text { VITA - BÜFÉ }
$$

Minden érdeklődőt szeretettel várunk. 